\section{Temas em psiquiatria forense e psicologia jurídica}

Sérgio Paulo Rigonatti, coordenador. Antonio de Pádua Serafim, Edgard Luiz de Barros, organizadores. São Paulo, Vetor Editora Psico-Pedagógica, 2003. ISBN 85-7585-021-0.

Observa-se nos últimos anos um renovado interesse pela prática da psiquiatria forense, tanto no Brasil quanto no exterior. Esse fato deve-se a uma conjugação de fatores. Por um lado, o aviltamento do mercado médico, com a limitação de ganhos impostos pelas empresas de seguro de saúde, torna a prática forense um novo e fascinante campo infenso à ação dessas predadoras; por outro, as crescentes complexidades legais e bioéticas na prática médica, o aumento de processos por erro médico e a epidemia de violência urbana fazem necessário que mais profissionais se dediquem a essa área de atividade. Não é de estranhar, portanto, que nos Estados Unidos, país onde viceja a cultura do recurso aos tribunais, ocorra uma bem identificada migração de psiquiatras para a prática forense. O mesmo fenômeno, em escala menor, constata-se atualmente no Brasil, o qual se comprova através da frequiência maciça de público, durante os congressos nacionais e regionais de psiquiatria, simpósios e mesas-redondas que tratem de temas forenses, legais e bioéticos.

Diferentemente, porém, dos países de língua inglesa onde existe uma permanente produção científica em psiquiatria forense, a qual abrange os mais variados temas - capacidade civil e penal, maus tratos, periculosidade, avaliação de testemunho, validade de consentimento e a prática clínica em ambiente penitenciário - em nosso país observa-se uma grande lacuna bibliográfica. O Índice Bibliográfico Brasileiro, de Walmor Piccinini, relaciona apenas 800 trabalhos desde o século XIX até nossos dias, a maioria dos quais anteriores a 1960. Assim, urge que sejam intensificados esforços editoriais e que novos projetos de pesquisa sejam implementados e seus resultados publicados em revistas de ponta.

"Temas em Psiquiatria Forense e Psicologia Jurídica" - produzido pelo grupo do Núcleo de Estudos e Pesquisas em Psiquiatria Forense e Psicologia Jurídica do Instituto de Psiquia- tria do HCFMUSP, sob a liderança do ilustre colega Dr. Sérgio Paulo Rigonatti - insere-se dentro desse contexto de necessidades. A obra discorre sobre temas variados, mantendo, entretanto, organicidade. Assim, inicia abordando aspectos históricos da prática forense, discorre sobre problemas fundamentais como a etiologia do comportamento criminoso, o papel da família na gêne-

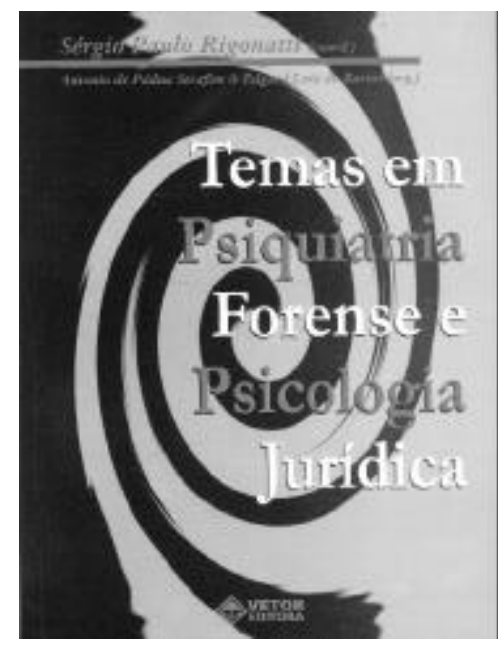
se e na recuperação do delinqüiente, a violência doméstica, a relação entre álcool e drogas e crime, a questão dos transtornos factícios e da simulação e da psiquiatria clínica em setting penitenciário. Discute a Lei de Execução Penal e as avaliações a ela inerentes, bem como o papel do psicólogo e do assistente social no sistema penitenciário. Finaliza com interessante capítulo no qual são apresentadas "Perspectivas Internacionais em Psiquiatria Forense", ou seja, um corte transversal comparativo da situação atual em alguns países. O leitor atento, entretanto, perceberá a ausência de um capítulo sobre capacidade penal (imputabilidade) e constatará que o capítulo sobre capacidade civil, apesar de muito bem escrito, está totalmente estruturado de acordo com os termos do Código Civil de 1916, recentemente revogado. São falhas menores que, de forma alguma, empanam a importância global dessa obra. O Dr. Sérgio Paulo Rigonatti e seus dedicados colaboradores estão, pois, de parabéns pela importante iniciativa tomada, havendo produzido livro que deverá se inscrever com relevo na bibliografia da psiquiatria forense brasileira.

José G. V. Taborda

Departamento de Psiquiatria e Medicina Legal, Fundação Faculdade Federal de Ciências Médicas de Porto Alegre 